\title{
Mycorrhizal Inoculation Effect on Sweet Potato (Ipomoea batatas (L.) Lam) Seedlings
}

\author{
Nour ALHadidi ${ }^{1}$, Zoltán Pap ${ }^{2}$, Márta Ladányi ${ }^{3}$,, Viktor Szentpéteri ${ }^{4}$ and Noémi Kappel ${ }^{1, * \mathbb{C}}$ \\ 1 Department of Vegetable and Mushroom Growing, Institute of Horticulture, Hungarian University of \\ Agriculture and Life Sciences, Villányi út 29-43, H-1118 Budapest, Hungary; noorhadidi_1992@hotmail.com \\ 2 Control Union Hungaria Kft, Kalapács u. 19/A, 1148 Budapest, Hungary; zpap@controlunion.com \\ 3 Department of Applied Statistics, Institute of Mathematics and Basic Science, Hungarian University of \\ Agriculture and Life Sciences, Villányi út 29-43, H-1118 Budapest, Hungary; ladanyi.marta@uni-mate.hu \\ 4 Department of Microbiology and Applied Biotechnology, Institute of Genetics and Biotechnology, Hungarian \\ University of Agriculture and Life Sciences, Páter Károly út 1, H-2100 Gödöllő, Hungary; \\ Szentpeteri.Viktor@phd.uni-mate.hu \\ * Correspondence: kappel.noemi@uni-mate.hu; Tel.: +36-30-215-8922
}

Citation: ALHadidi, N.; Pap, Z.; Ladányi, M.; Szentpéteri, V.; Kappel, N. Mycorrhizal Inoculation Effect on Sweet Potato (Ipomoea batatas (L.) Lam) Seedlings. Agronomy 2021, 11, 2019. https://doi.org/10.3390/ agronomy11102019

Academic Editor: Samantha

C. Karunarathna

Received: 1 August 2021

Accepted: 2 October 2021

Published: 8 October 2021

Publisher's Note: MDPI stays neutral with regard to jurisdictional claims in published maps and institutional affiliations.

Copyright: (c) 2021 by the authors. Licensee MDPI, Basel, Switzerland. This article is an open access article distributed under the terms and conditions of the Creative Commons Attribution (CC BY) license (https:// creativecommons.org/licenses/by/ $4.0 /)$.

\begin{abstract}
Sweet potato is an increasingly significant crop and its effective and sustainable cultivation has become important in temperate countries. The purpose of this pilot study was to investigate the effects of a mycorrhizal inoculum, Symbivit, and whether it could establish a symbiotic relationship with the seedlings of two sweet potato varieties (orange and purple). The effectiveness of the mycorrhizal inoculation with a sterilized substrate on the mycorrhizal parameters ( $\mathrm{F} \%, \mathrm{M} \%, \mathrm{~m} \%, \mathrm{a} \%$, $\mathrm{A} \%$ ) and physical parameters "[length of roots and shoots $(\mathrm{cm})$, the fresh weight of shoots and roots (g) as well as the length of stem (cm)]" on the sweet potato seedlings has also been studied. Results show that the sterilization treatment with Symbivit in both varieties increased the frequency of mycorrhiza in the root system. For the intensity of the mycorrhizal colonization in the root fragments and the arbuscular abundance, there was a difference between the mycorrhizal inoculum and the sterilization treatment among the varieties. Overall, the preliminary results provided remarkable information about mycorrhizal inoculation, substrate sterilization on mycorrhizal development, as well as changes in the physical parameters between sweet potato seedlings. Our results could serve as a practical strategy for further research into adding significance to the effect of the beneficial soil microbes on sweet potatoes.
\end{abstract}

Keywords: mycorrhizal parameters; physical parameters; sterilization; sweet potato seedling; varieties

\section{Introduction}

Sweet potato (Ipomoea batatas (L.) Lam.) belongs to the Convolvulaceae family [1]. Currently, this plant is mostly grown in tropical and subtropical areas, with adequate water supply [2]. In 2019, 51, 992, 156 tons of sweet potato were produced in China [3]. Sweet potato contains many secondary metabolites, particularly antioxidant compounds including anthocyanins, carotenoids and vitamin $C[4,5]$. On the other hand, tubers also contain high amounts of minerals likes zinc, potassium, sodium, manganese, calcium, magnesium, and iron. They are also rich in carbohydrates and fibre [6].

Sweet potato can be grown in loam, clay loam and sandy loam soils. However, sandy loam with clay subsoil is one of the best for the growth of the sweet potato. Heavily clayed soil restricts root development, while sandy soil encourages the elongation of the root into the deep soil [7]. Worldwide, sweet potato has a lot of varieties and usually, countries have their own varieties. For instance, in the USA, more than 50 varieties are grown [8].

Mycorrhizal fungi and host plant symbiosis were important in the evolution of terrestrial plants and this relationship can be detected in more than $80 \%$ of vascular plant 
species [9]. The first fossils documenting the mutualistic association between plants and soil fungi known as arbuscular mycorrhiza (AM) with more than 400 million years old [10]. AM fungi belong to the phylum Glomeromycota [11] and it is a form of endomycorrhiza, which means that internal hyphae penetrate the root cells [12]. AM fungi are biostimulants and they occur everywhere in soil ecosystems [13]. Most essential nutrients that are important for the host plants such as phosphate, nitrogen, potassium and sulfate can be obtained by the fungal hyphae through different transporters [14].

One more beneficial function of AM symbiosis is that the arbuscular mycorrhizal fungi can increase the tolerance of the host plant for environmental stress such as drought, salinity and heavy metals and this leads to improved growth and development in unfavourable conditions [15]. Numerous mechanisms have been suggested to interpret the host plant protection effects of AM symbiosis from environmental stress, such as changes in plant hormones, the boost of the photosynthetic ratio and ROS scavenging [16].

One of the most destructive environmental stressors is drought, which limits crop growth and yield [17]. When a plant is exposed to drought stress, its membrane system becomes damaged and water dispersal becomes irregular [18]. In addition, the formation of reactive oxygen species such as superoxide radical $\left(\mathrm{O}_{2}{ }^{-}\right)$, hydrogen peroxide $\left(\mathrm{H}_{2} \mathrm{O}_{2}\right)$ and hydroxyl radical $\left(\mathrm{OH}^{-}\right)$intensifies [19]. Reactive oxygen species are manufactured through the respiration of the mitochondria and during photosynthesis in the chloroplast [20].

Sweet potato can be grown in two ways: from tubers and shoots. Growing from tubers is done with seeds of $20-50 \mathrm{~g}$ sown to a depth of $3 \mathrm{~cm}$, but this method results in a significantly lower yield. The widespread method of using cuttings is more preferable to propagate the plant so that to achieve higher yield and more favourable shape and size tubers [21].

Sweet potato can be propagated vegetatively by planting cuttings with sprouting tubers [22]. It is important to use first-class tubers in order to preserve varietal characteristics [23]. The first-class tubers must be in good shape, free from pathogens and pests and they should receive appropriate treatment before storage, which must be carried out separately from the other tubers [24].

To our knowledge, little is known in the literature concerning the influence of arbuscular mycorrhizal fungi on sweet potato varieties. Thus, our focus of in this pilot study is quite new as it highlights the differences of two sweet potato varieties (orange and purple) in various parallel tests such as the applied inoculation method. The main aims of the current study are to investigate if the mycorrhizal inoculum is effective in developing a symbiotic relationship with sweet potato (Ipomoea batatas (L.) Lam.) roots, which will affect the physiological and physical parameters of the plant; furthermore, to examine if the sterilization of the substrate has an influence on the mycorrhizal colonization.

\section{Materials and Methods}

\subsection{Experiment Design}

The experiment was set up in the spring of 2019 at Budai Campus of the Hungarian University of Agriculture and Life Sciences, at the experimental glasshouse of the Department of Vegetable and Mushroom Growing $\left(47.28^{\circ} \mathrm{N}, 19.04^{\circ} \mathrm{E}\right)$. Two sweet potato varieties were used: orange: "Norangel" and purple "Purple". The seedlings were grown in a plastic pot $(1.5 \mathrm{~L}(11.5 \mathrm{~cm} \times 12 \mathrm{~cm} \times 15 \mathrm{~cm}))$. For seedling production, non-treated ground/minced peat) was used as a growing medium from Latagro Basic Substrat KB2 type (white peat $100 \%(0-10 \mathrm{~mm})$ with specification: $\mathrm{pH}$ value $\left(\mathrm{H}_{2} \mathrm{O}\right) 6.4$; soluble nutrients available to the plants: Nitrogen $<7 \mathrm{mg} / \mathrm{L}$; Phosphate $<7.8 \mathrm{mg} / \mathrm{L}$; Potassium oxid $<40 \mathrm{mg} / \mathrm{L}$ ). Mycorrhizal inoculation was performed with Symbivit (Symbiom Ltd. product from Sazava 170, 56301 Lanskroun, Czech Republic, mycorrhizal, composition: five species of mycorrhizal fungi (Claroideoglomus etunicatum, Claroideoglomus claroideum, Rhizophagus irregularis, Funneliformis geosporus, Funneliformis mosseae), natural minerals, sapropel, extracts from sea organisms, natural keratin, humates and powdered biodegradable water-storing 
polymer granules; the bioadditive part represents $110 \mathrm{~g}$ in each $\mathrm{Kg}$ of product) [25]. For $1 \mathrm{~L}$ of the substrate, $15 \mathrm{~g}$ of Symbivit was mixed.

The experiment was made with three treatments for each variety in three replications; in each treatment, 15 seedlings were used with a total of 45 seedlings. In each pot, one seedling was used (applied). Table 1 shows the code of the treatments. There was no additional nutrient replenishment during seedling cultivation. For the inoculation experiment, half of the peat moss was sterilized to detect if the sterilization has any influence on the mycorrhizal inoculation efficiency. Peat moss was sterilized at the mushroom lab in the Department of Vegetable and Mushroom Growing by a trade Raypa steam sterilizer at a temperature of $121{ }^{\circ} \mathrm{C}$ for $20 \mathrm{~min}$. Temperature and humidity were measured during the experiment by Voltcraft co. DL-181THP data logger. The maximum temperature was $33.12^{\circ} \mathrm{C}$, the minimum was $16.14^{\circ} \mathrm{C}$. Maximum relative humidity was $88.44 \%$. As a control, the soil of the experimental farm was used in which previous experiments had already shown mycorrhizal colonization $\left(\mathrm{pH}(\mathrm{KCl}) 7.45 ; \mathrm{NO}_{2}+\mathrm{NO}_{3}-\mathrm{N}(\mathrm{mg} / \mathrm{kg}) 71.6 ; \mathrm{P}_{2} \mathrm{O}_{5}(\mathrm{mg} / \mathrm{kg})\right.$ $\left.577 ; \mathrm{K}_{2} \mathrm{O}(\mathrm{mg} / \mathrm{kg}) 166\right)$.

Table 1. Treatments used during the experiment per variety.

\begin{tabular}{cccc}
\hline Substrate & Number & Treatment Code & Treatment Description \\
\hline Non-Sterilized Peat Moss & 1 & $(\mathrm{~L}+\mathrm{SYM})$ & Non sterilized peat moss with mycorrhizal inoculum \\
Sterilized Peat Moss & 2 & $(\mathrm{~L}+\mathrm{SYM}) . \mathrm{S}$ & Sterilized peat moss with mycorrhizal inoculum \\
Soil from experimental farm (Control) & 3 & $\mathrm{~F}$ & Soil from experimental farm \\
\hline
\end{tabular}

The roots were sampled on the 8th week after transplanting. In addition, several physical parameters were measured manually by ruler: the length of roots and shoots $(\mathrm{cm})$, the length of the stem $(\mathrm{cm})$ as well as the fresh weight of shoots and roots $(\mathrm{g})$ of the seedlings for both varieties were measured by electronic balance. Ink based staining was carried out using the method suggested by Phillips and Hayman (1970) [26].

\subsection{Determination of Colonization}

Colonization was determined according to the method of Trouvelot et al. [27]. Based on the equation proposed by Trouvelot et al., all parameters of colonization were calculated and expressed as a percentage by using Mycocalc software (developed by Biro Zsombor: frequency calculations were performed using a Windows forms application written in $\mathrm{C} \#$ and developed to facilitate the process, based on the equations of Trouvelo et al. (1986)). (F\%: Frequency of mycorrhiza in the root system, M\%: Intensity of the mycorrhizal colonization in the root system, $\mathrm{m} \%$ : Intensity of the mycorrhizal colonization in the root fragments, a\%: Arbuscular abundance in mycorrhizal parts of roots fragments, $\mathrm{A} \%$ : Arbuscular abundance in the root system. Slides were prepared to check the hyphal and the arbuscular development by Zeiss Axio CAM Hr3 microscope camera.

\subsection{Statistical Analysis}

Data analysis was carried out with IBM SPSS 25 software (Version 25.0. Armonk, NY: IBM Corp [28]. The fresh weight of shoots and roots (g), as well as the root and stem lengths, were analyzed by two-way MANOVA model with factors variety (orange and purple) and treatment levels ( $\mathrm{L}+\mathrm{SYM}) . \mathrm{S}, \mathrm{F}, \mathrm{L}+\mathrm{SYM})$. The normality of the residuals was tested by Shapiro-Wilk method (K (74) $>0.95 ; p>0.05$ ). Having an overall significant MANOVA result, we ran follow-up univariate ANOVA tests with Bonferroni's correction. In some cases, the homogeneity of variances was slightly violated (Levene's $0.05>p>0.02$ ), so pairwise comparisons of the treatments were performed by the Games-Howell post hoc test. 


\section{Results}

\subsection{Proof of Symbiotic Relation Establishment}

(Figure 1I,II) indicate that mycorrhizal inoculum (Symbivit) in a sterilized peat moss established a symbiotic relationship with sweet potato seedlings for both varieties, orange and purple. In the case of control seedlings, we could observe hyphal and arbuscular development in as well.

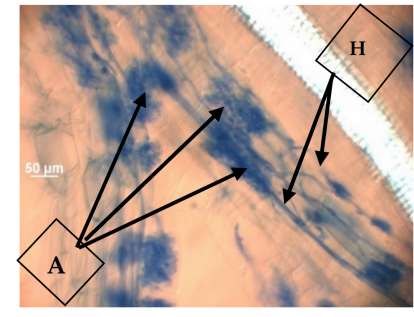

I: Treatment $(\mathrm{L}+\mathrm{SYM}) . \mathrm{S}$

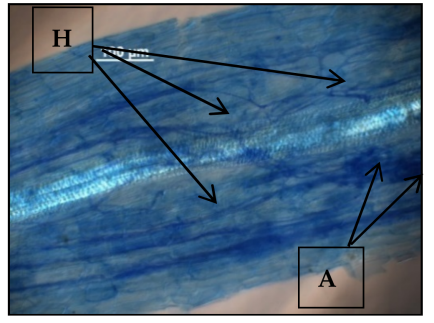

II: Treatment control (F)

Figure 1. (I): Sweet potato seedlings treated with mycorrhizal inoculum in a sterilized form with the hyphal $(\mathrm{H})$ and the arbuscular development (A). (II): Dense arbuscular formation in control sweet potato seedlings. Arbuscular mycorrhiza could also develop in both varieties when they were treated with soil from the experimental and research farm $(\mathrm{F})$. The hyphal development $(\mathrm{H})$ and the arbuscular establishment (A) can also be observed.

\subsection{Mycorrhizal Parameters}

According to Table 2, the highest frequency of mycorrhizal fungi in the root system $(\mathrm{F} \%)$ in purple variety was found in (L+SYM).S, while the control treatment $\mathrm{F}$ had the lowest frequency of mycorrhizal colonization. In the orange variety, the highest frequency of mycorrhizal colonization was recorded in (L+SYM).S and the lowest one was found in treatment $\mathrm{F}$. The sterilization treatment with Symbivit in both varieties orange and purple increased the frequency of colonization in the root system.

Table 2. Mycorrhizal parameters (F\%, $\mathrm{A} \%, \mathrm{a} \%, \mathrm{M} \%$ and $\mathrm{m} \%)$ within different treatments and varieties.

\begin{tabular}{ccccccc}
\hline Variety & Treatment & F\% & $\mathbf{M} \%$ & $\mathbf{m} \%$ & $\mathbf{a} \%$ & $\mathbf{A} \%$ \\
\hline \multirow{3}{*}{ purple } & L+SYM & 20.22 & 11.49 & 58.07 & 86.82 & 9.97 \\
& (L+SYM).S & 84.86 & 42.73 & 50.29 & 5.38 & 2.40 \\
\hline \multirow{2}{*}{ orange } & F & 4.52 & 1.25 & 36.50 & no arbuscule & no arbuscule \\
& L+SYM & 21.63 & 0.32 & 1.47 & no arbuscule & no arbuscule \\
& F+SYM).S & 67.19 & 21.44 & 32.13 & 35.28 & 7.59 \\
\hline F $\%:$ Freque & 15.89 & 2.82 & 18.67 & no arbuscule & no arbuscule \\
\hline
\end{tabular}

F\%: Frequency of mycorrhiza in the root system, M\%: Intensity of the mycorrhizal colonization in the root system, $\mathrm{m} \%$ : Intensity of the mycorrhizal colonization in the root fragments, $\mathrm{a} \%$ : Arbuscular abundance in mycorrhizal parts in root fragments, $\mathrm{A} \%$ : Arbuscular abundance in the root system.

We measured the high intensity of the mycorrhizal colonization in the root system $(\mathrm{M} \%)$ of purple variety in (L+SYM).S treatment compared to the treatments (L+SYM) with medium and control $\mathrm{F}$ with low mycorrhizal intensity (Table 2). In the orange variety, the sterilization treatment $(\mathrm{L}+\mathrm{SYM})$.S had also the highest mycorrhizal intensity but the $\mathrm{L}+\mathrm{SYM}$ without sterilization had the lowest intensity of the mycorrhizal colonization in the root fragments $(\mathrm{m} \%)$.

The arbuscular abundance in the mycorrhizal parts $(\mathrm{a} \%)$ showed that in the purple variety notably higher percentage was recorded in L+SYM than in (L+SYM). S. However, in $\mathrm{F}$ treatment, no arbuscules were found, although, in the orange variety, arbuscules were recorded only in L+SYM.S treatment while in L+SYM and F treatment no arbuscules were found. 
As for the arbuscular abundance in the root system (A\%), in the purple variety, the highest arbuscular abundance was recorded in L+SYM followed by L+SYM.S while in $\mathrm{F}$ treatment no arbuscules were found. For the orange variety, arbuscules were found only in L+SYM.S treatment while in L+SYM and in the control treatment no arbuscules were detected.

\subsection{Physical Parameters of Sweet Potato Transplants}

The two-way MANOVA resulted in significant variety and treatment effects (Wilk's lambda $=0.48, p<0.001$; Wilk's lambda $=0.18, p<0.001$, respectively) with significant interaction (Wilk's lambda $=0.64, p<0.05$ ). The follow-up univariate ANOVA was significant in cases of fresh weight of shoots and the length of the stem both for variety and treatment $(\mathrm{F}(1 ; 38>6.48 ; p<0.05)$ and in case of the fresh weight of the total roots for the treatment effect $(\mathrm{F}(4 ; 38)=7.90 ; p<0.01)$ as well as for their interaction in case of fresh weight of shoots and the length of stem $(\mathrm{F}(4 ; 38)>4.88 ; p<0.01)$. The variety effect was not significant in cases of the fresh weight of the total roots and the length of the roots $((\mathrm{F}(4 ; 38)<3.15 ; p>0.08)$ and the treatment effect was insignificant in case of the length of the roots $(\mathrm{F}(4 ; 38)=3.13 ; p=0.06)$. The means and standard deviations of the four physical parameters together with the post hoc tests results are summarized in Table 3.

Table 3. Means and standard deviations of the four physical parameters fresh weight of shoots (g), fresh weight of total roots $(\mathrm{g})$, length of roots $(\mathrm{cm})$ and length of stem $(\mathrm{cm})$ together with the post hoc tests results (Games-Howell's; $p<0.05)$. The different letters are for significantly different groups (lower case: comparison of treatments for fixed varieties-read vertically), upper case: comparison of varieties for fixed treatments-read horizontally).

\begin{tabular}{|c|c|c|c|c|c|c|c|c|c|}
\hline \multirow{2}{*}{$\begin{array}{c}\text { Variety } \\
\text { Parameters }\end{array}$} & \multirow[b]{2}{*}{ Treatment } & \multicolumn{4}{|c|}{ Orange } & \multicolumn{4}{|c|}{ Purple } \\
\hline & & Mean & Std. Dev & $\begin{array}{l}\text { Comparison } \\
\text { of Treatments }\end{array}$ & $\begin{array}{l}\text { Comparison } \\
\text { of Varieties }\end{array}$ & Mean & Std. Dev & $\begin{array}{l}\text { Comparison } \\
\text { of Treatments }\end{array}$ & $\begin{array}{l}\text { Comparison } \\
\text { of Varieties }\end{array}$ \\
\hline \multirow{3}{*}{$\begin{array}{c}\text { FW of } \\
\text { shoots }(g)\end{array}$} & (L+SYM).S & 4.76 & 0.88 & $\mathrm{a}$ & $\mathrm{A}$ & 3.80 & 2.99 & $a^{1}$ & A2 \\
\hline & $\mathrm{F}$ & 2.83 & 1.73 & $\mathrm{a}$ & $\mathrm{A}$ & 9.42 & 3.04 & $\mathrm{~b}^{1}$ & B2 \\
\hline & L+SYM & 11.43 & 3.85 & $\mathrm{~b}$ & A & 15.81 & 4.32 & $c^{1}$ & A2 \\
\hline \multirow{3}{*}{$\begin{array}{l}\text { FW total } \\
\text { roots }(g)\end{array}$} & (L+SYM).S & 4.89 & 1.14 & $\mathrm{~b}$ & A & 3.88 & 2.38 & $a^{1}$ & $\mathrm{~A} 2$ \\
\hline & $\mathrm{F}$ & 1.09 & 0.89 & $\mathrm{a}$ & A & 3.44 & 1.87 & $a^{1}$ & B2 \\
\hline & L+SYM & 4.79 & 1.87 & $\mathrm{~b}$ & A & 5.89 & 2.97 & $a^{1}$ & A2 \\
\hline \multirow{3}{*}{$\begin{array}{l}\text { Length of } \\
\text { roots }(\mathrm{cm})\end{array}$} & (L+SYM).S & 35.52 & 6.26 & $\mathrm{a}$ & A & 36.13 & 13.58 & $\mathrm{a}^{1}$ & $\mathrm{~A} 2$ \\
\hline & $\mathrm{F}$ & 23.17 & 8.69 & $\mathrm{a}$ & A & 32.74 & 6.54 & $a^{1}$ & B2 \\
\hline & L+SYM & 25.90 & 7.44 & $\mathrm{a}$ & A & 30.83 & 8.30 & $a^{1}$ & A2 \\
\hline \multirow{3}{*}{$\begin{array}{l}\text { Length of } \\
\text { stem }(\mathrm{cm})\end{array}$} & (L+SYM).S & 35.56 & 12.89 & a & B & 14.69 & 5.80 & $\mathrm{a}^{1}$ & $\mathrm{~A} 2$ \\
\hline & $\mathrm{F}$ & 20.00 & 11.21 & $\mathrm{a}$ & A & 29.37 & 7.83 & $\mathrm{~b}^{1}$ & $\mathrm{~A} 2$ \\
\hline & L+SYM & 75.32 & 36.27 & $\mathrm{~b}$ & A & 47.69 & 14.72 & $c^{1}$ & $\mathrm{~A} 2$ \\
\hline
\end{tabular}

${ }^{1}$ Comparison of treatments for fixed varieties—read vertically; 2 comparison of varieties for fixed treatments—read horizontally.

The highest mean of shoot fresh weight for orange sweet potato seedlings was found in L+SYM treatment (11.43 g). There was no significant difference between treatments (L+SYM). S and F, so we concluded, that the mycorrhizal inoculum could increase shoot weight by the time, while sterilization had no increasing effect on shoot weight $(\mathrm{g})$ in case of treated orange sweet potato seedlings (Table 3). The highest fresh shoot weight in purple sweet potato seedlings was under the treatment L+SYM with a mean of (15.81 g) whilst (L+SYM). S treatment resulted in the lowest mean $(3.80 \mathrm{~g})$, i.e., the mycorrhizal inoculation also increased the fresh weight of shoot in the purple sweet potato seedlings, whereas the sterilization had no effect on the fresh weight of shoot (Table 3).

The highest weight of roots was detected in orange sweet potato seedlings with the highest mean in (L+SYM). S treatment $(4.89 \mathrm{~g})$, while the lowest mean was found in control treatment $(\mathrm{F})$ with a mean of $(1.09 \mathrm{~g})$. This means, that mycorrhizal inoculation and the sterilization had a high effect on the weight of roots in orange sweet potato seedlings (Table 3). 
For the weight of roots of purple sweet potato seedlings, the highest mean value was in the L+SYM treatment (5.89 g) while the lowest mean value was in F treatment with a mean $(3.44 \mathrm{~g})$. This is because the mycorrhizal inoculation had a stimulating effect on the fresh roots weight of purple sweet potato seedlings (Table 3).

The highest length of roots in orange sweet potato variety was measured in seedlings treated by Symbivit in sterilized substrate (peat moss) (L+SYM). The S treatment resulted in a mean value of $(35.52 \mathrm{~cm})$. However, there was no significant difference between the mean values when comparing the three levels of treated orange sweet potato seedlings. Therefore, mycorrhizal inoculation with sterilization had no effect on the length of the roots in the orange sweet potato seedlings (Table 3).

The highest mean of the root length $(36.13 \mathrm{~cm})$ was measured in the purple sweet potato seedlings propagated in a sterilized Latagro peat moss with Symbivit (L+SYM).S treatment. However, differences between the treated seedlings were not significant (Table 3).

The highest mean of stem length in orange sweet potato seedlings was measured in $\mathrm{L}+\mathrm{SYM}$ treatment $(75.32 \mathrm{~cm})$ while the lowest mean value was in F treatment $(20.00 \mathrm{~cm})$. Accordingly, mycorrhizal inoculation could increase the length of the stems in the orange sweet potato seedlings. On the other hand, sterilization had no increasing effect on the length of the stems in orange sweet potato seedlings (Table 3).

In the purple sweet potato seedlings, the highest length of stem was measured in L+SYM $(47.69 \mathrm{~cm})$ while the lowest mean value was in treatment $(\mathrm{L}+\mathrm{SYM}) . \mathrm{S}(14.69 \mathrm{~cm})$. The mycorrhizal inoculation resulted in a positive influence on the length of roots. However, the sterilization had no stimulating effect on the length of roots in purple sweet potato seedlings.

\section{Discussion}

Sweet potato originates from Central America and it has been cultivated widely in tropical and subtropical countries like Malaysia, Indonesia, China, USA and Japan [29,30]. In Malaysia, for instance, they have been cultivated for a long time and have become one of the country's major vegetable crops due to them being an inexpensive source for energy, carotene, ascorbic acid, niacin, riboflavin, thiamine and minerals [31]. Recently, temperate countries like Hungary have started its cultivation [32]. The increasing demands for sweet potato have also encouraged growers and led to an increase in the cultivation area of sweet potato around Hungary [5]; however, little is known about its cultivation in this climate. During its cultivation technology seed root selection involves the process of selecting, curing and storing sweet potato roots for the production of slips or also known as vine cuttings [33]. This is important to ensure high quality slips which will lead to the establishment and production of high-yielding sweet potato crops [24], which can be differentiated through their flesh color. The most common ones are like potato's flesh color, with a range from white to yellow [30].

The present study showed that the used mycorrhizal inoculum could establish a symbiotic relationship with the treated and control sweet potato seedlings. The confirmation of the establishment can be shown by the calculated mycorrhizal parameters (Table 2). Gai et al. also showed that several mycorrhizal fungi species are able to colonize sweet potato to various degrees [34]. More than $90 \%$ of plant species are able to establish symbiotic relationship with arbuscular mycorrhizal fungi, which indicates their common abundance [35]. This is also visible in our findings as sweet potato grown on control soil also showed signs of colonization. Arbuscular mycorrhizal fungi have effectively inoculated cotton, tomato, pepper, horse bean, garlic, soybean, cucumber, melon, watermelon, maize and eggplant plants [36]. In order to ensure the colonization, a few circumstances must be met, which are the use of a variety of arbuscular mycorrhizal fungi species simultaneously, with a high amount of infective propagules, the absence of pathogens and pests, the availability of beneficial bacterial additives and the use of dry solid inoculums [37]. These requirements were observable in our results as well, as colonization was the highest when the commercial 
inoculant with several AMF species and controlled propagule number was used, while the growth medium was sterilized and was free of pests and pathogens.

Arbuscular mycorrhizal fungi can promote plant growth directly and indirectly. It can directly promote the growth of the root system through the modulation of the phytohormones of the host, which leads to its indirect growth promotion through the increased availability of some immobile nutrients through the increased root zone [38-40]. Besides immobile nutrient, mycorrhiza can also help accumulate nitrogen from its different forms like nitrate $\left(\mathrm{NO}^{-}\right)$, ammonium $\left(\mathrm{NH}_{4}{ }^{+}\right)$and amino acids using their extraradical hyphae [41]. Some studies proved the positive effect of arbuscular mycorrhizal fungi towards absorption of phosphorus, nitrogen, potassium, magnesium, copper, zinc, calcium, iron cadmium and nickel $[14,42]$. Arbuscular mycorrhizal symbiosis can affect biochemical and physiological processes such as protection towards oxidative damage, improved water usage efficiency, weight of shoots, improved gas exchange rate, and enhanced osmotic regulation [43,44]. It is obvious from our results of fresh shoots and root weights that mycorrhizal inoculation could enhance the physical parameters of sweet potato seedlings.

Several other studies have already shown the positive effect of AMF on physical parameters. In maize, it was proven that Glomus intraradices has the ability to promote shoot and root dry weight [45]. Kakabouki et al. [46] examined the effect Rhizophagus irregularis on cannabis seedlings and found significantly increased root length, stem dry weight, and improvement in survival rate and phosphorous content. In another study it is also confirmed that Arbuscular mycorrhizal fungi increased sweet potato shoot and root fresh weights for PROC 65-3 (white-fleshed) and Tainung 57 (orange-fleshed) sweet potato varieties [47]. In addition, in the study of Sakha and Jefwa [48], two sweet potato varieties, Kemb-10 and Bungoma, were examined with and without AMF inoculation focusing on physical parameters, namely on the number of branches, vine length and yield. They found that mycorrhizal inoculation improved the yield and growth [49]. The yield of storage roots is positively correlated to the vegetative characteristics and the correlation with the number of leaves per plants is significant [50]. In terms of the length of roots, we found no positive effect of the mycorrhizal inoculation while there was an increasing in the length of stem. The effect of the sterilization treatment was low; the reason behind this might be that the microbial population in autoclaved growth medium was lower than in the non-autoclaved growth media. This is in accordance with the results of Köhl et al. [51].

Nevertheless, the defined impact of AMF on plant growth and development is not stable due to the complex relation between the AMF, the inoculation method and the environmental conditions [52]. It was visible in our results that although the highest colonization rates were found in sweet potato grown on sterilized peat, the treatment was not performing better in terms of the physical parameters when compared to non-sterilized inoculated treatments. Moreover, this can be assured by other studies finding that plants with high rates of mycorrhizal colonization can be obtained on peat-based substrate but that under these conditions, plants may not consistently benefit in growth from the mycorrhizal symbiosis [53]. Likewise, the interaction amongst arbuscular mycorrhizal species may differ between sweet potato varieties [54]. In our experiment, the mycorrhizal inoculum seemed to have an equalizing effect on the varieties, as the significant differences during control found that the fresh weights of shoot and root, and root length were missing during both mycorrhizal treatments.

\section{Conclusions}

In this pilot study, we examined the ability of the mycorrhizal inoculum product Symbivit to establish an association with two varieties of sweet potato seedlings, orange and purple. The results showed that the symbiotic relationship was successfully developed; we could observe this by the scoring of the mycorrhizal colonization in stained roots under microscope. We could detect different mycorrhizal developmental structures such as hyphae and arbuscules, especially in the seedlings that were treated with Symbivit in sterilized peat moss. According to our observations, substrate sterilization may influence 
the mycorrhizal colonization development during the plant growth. The mycorrhizal inoculation with a sterilized substrate had a different effect among the varieties on the physical parameters of the seedlings. This study suggested that inoculation of sweet potato seedlings with AMF can be functional, which presumably improves plant growth, nutrient uptake, and significantly improves sweet potato yield.

Author Contributions: Conceptualization and methodology Z.P.; writing-original draft preparation N.A., M.L. and V.S.; validation, analysis, and visualization, N.A. and M.L.; writing-review and editing, N.K.; revision N.K. All authors have read and agreed to the published version of the manuscript.

Funding: This research was funded by the Ministry for Innovation and Technology within the framework of the Thematic Excellence Program 2020-Institutional Excellence Subprogram (TKP2020IKA-12) for research on plant breeding and plant protection. In addition, funding was received from the "ÚNKP-20-3-II" New National Excellence Program of the Ministry of Human Capacities.

Institutional Review Board Statement: Not applicable.

Informed Consent Statement: Not applicable.

Data Availability Statement: The data presented in this study are available on request from the authors.

Conflicts of Interest: The authors declare no conflict of interest.

\section{References}

1. Zhao, D.; Wu, S.; Dai, X.; Su, Y.; Dai, S.; Zhang, A.; Zhou, Z.; Tang, J.; Cao, Q. QTL Analysis of root diameter in a wild diploid relative of sweet potato (Ipomoea batatas (L.) Lam.) Using a SNP-based genetic linkage map generated by genotyping-bysequencing. Genet. Resour. Crop. Evol. 2021, 68, 1375-1388. [CrossRef]

2. Azevedo, A.M.; Valter, C.; Andrade, J. Influence of harvest time and cultivation sites on the productivity and quality of sweet potato. Hortic. Bras. 2014, 32, 21-27. [CrossRef]

3. FAOSTAT. Available online: http:/ / www.fao.org (accessed on 6 January 2021).

4. Teow, C.C.; Truong, V.D. Antioxidant activities, phenolic and $\beta$-carotene contents of sweet potato genotypes with varying flesh colours. Food Chem. 2007, 103, 829-838. [CrossRef]

5. Szarvas, A.; Herczeg, E.; Papp, L.; Monostori, T. The Effect of Planting Density on the Yield of Sweet Potato Ipomoea Batatas (L.) Lam. in South-East Hungary. Res. J. Agric. Sci. 2018, 50, 159-163.

6. Ambika, A.P.; Nair, S.N. Wound healing activity of plants from the Convolvulaceae family. Adv. Wound Care 2019, 8, 28-37. [CrossRef]

7. Nedunchezhiyan, M.; Ray, R.C. Sweet Potato Growth, Development, Production and Utilization: Overview. Sweet Potato: Post-Harvest Aspects in Food; Nova Science Publishers Inc.: New York, NY, USA, 2010; pp. 1-26.

8. Jackson, D.M.; Harrison, H.F., Jr. Insect resistance in traditional and heirloom sweet potato varieties. J. Econ. Entomol. 2013, 106, 1456-1462. [CrossRef]

9. Santander, C.; Aroca, R.; Ruiz-Lozano, J.M.; Olave, J.; Cartes, P.; Borie, F.; Cornejo, P. Arbuscular mycorrhiza effects on plant performance under osmotic stress. Mycorrhiza 2017, 27, 639-657. [CrossRef]

10. Gough, E.C.; Owen, K.J.; Zwart, R.S.; Thompson, J.P. A review of the effects of arbuscular mycorrhizal fungi and the root-lesion nematode Pratylenchus spp. Front. Plant Sci. 2020, 11, 923. [CrossRef]

11. Mohammed, M.K.; Hawar, S.N. Effect of Mycorrhiza Fungi Spread in Soil and Palm Roots on Phosphorus Potassium Content of Three Locations in Baghdad City. Plant Arch. 2020, 20, 2508-2512.

12. Fekete, K.; Al Hadidi, N.; Pap, Z. Effect on AM colonization and some Quality Parameters of Batavian Lettuce. In Water management: Focus on Climate Change; Hungarian University of Agriculture and Life Sciences: Szarvas, Hungary; Digitális Kalamáris Kiadó és Gyorsnyomda: Szarvas, Hungary, 2020; pp. 69-74.

13. Al Hadidi, N.; Pap, Z. The Effectiveness of the Arbuscular Mycorrhiza to Increase the Drought Stress Tolerance in Tomato Crop (Solanum lycopersicum. L.): A-Review. In Water management: Focus on Climate Change; Hungarian University of Agricultural and Life Sciences: Szarvas, Hungary; Digitális Kalamáris Kiadó és Gyorsnyomda: Szarvas, Hungary, 2020; pp. 125-129.

14. Wang, W.; Shi, J.; Xie, Q.; Jiang, Y.; Yu, N.; Wang, E. Nutrient Exchange and Regulation in Arbuscular Mycorrhizal Symbiosis. Mol. Plant 2017, 10, 1147-1158. [CrossRef] [PubMed]

15. Pimprikar, P.; Gutjahr, C. Transcriptional regulation of arbuscular mycorrhiza development. Plant Cell Physiol. 2018, 59, 673-679. [CrossRef] [PubMed]

16. Mayer, Z.; Duc, N.H.; Sasvári, Z.; Posta, K. How arbuscular mycorrhizal fungi influence the defense system of sunflower during different abiotic stresses. Acta Biol. Hung. 2017, 68, 376-387. [CrossRef] [PubMed] 
17. $\mathrm{Hu}, \mathrm{Y}$;; Chen, B. Arbuscular mycorrhiza induced putrescine degradation into $\gamma$-aminobutyric acid, malic acid accumulation, and improvement of nitrogen assimilation in roots of water-stressed maize plants. Mycorrhiza 2020, 30, 329-339. [CrossRef] [PubMed]

18. Zou, Y.N.; Wu, Q.S.; Kuča, K. Unraveling the role of arbuscular mycorrhizal fungi in mitigating the oxidative burst of plants under drought stress. Plant Biol. 2020, 23, 50-57. [CrossRef] [PubMed]

19. Czarnocka, W.; Karpinski, S. Friend or foe? Reactive oxygen species production, scavenging and signaling in plant response to environmental stresses. Free. Radic. Biol. Med. 2018, 122, 4-20. [CrossRef] [PubMed]

20. Mhamdi, A.; Van Breusegem, F. Reactive oxygen species in plant development. Development 2018, 145, dev164376. [CrossRef] [PubMed]

21. Onwueme, I.C.; Charles, W.B. Tropical Root and Tuber Crops-Production, Perspectives and Future Prospects; FAO Plant Production \& Protection Paper; FAO: Rome, Italy, 1994.

22. Horváth, L. The most important issues in the domestic cultivation of sweet potatoes. Plant Divers. Cent. 2015, 2.

23. Váraljai, T.; Bráj, R. Sweet potato beach, sweet potato production in Ivory Coast and in Hungary. Agroforum 2017, 1, 32-35.

24. Brandenberger, L.; Shrefler, J.; Rebek, E.; Damicone, J. Sweet Potato Production; HLA-6022; Oklahoma Cooperative Extension Service: Stillwater, OK, USA; Oklahoma State University: Stillwater, OK, USA, 2014.

25. Symbiom Ltd. Available online: https://www.symbiom.cz/en/p-3-symbivit (accessed on 15 September 2021).

26. Phillips, J.M.; Hayman, D.S. Improved procedures for clearing roots and staining parasitic and vesicular-arbuscular mycorrhizal fungi for rapid assessment of infection. Trans. Br. Mycol. Soc. 1970, 55, 158-161. [CrossRef]

27. Arbuscular Mycorrhizal Fungi in Plant Production Systems: Detection, Taxonomy, Conservation and Ecophysiology. Available online: https:/ / www2.dijon.inrae.fr/mychintec/Protocole/protoframe.html (accessed on 10 August 2020).

28. IBM Corp. IBM SPSS Statistics for Windows, Version 25.0; IBM Corp.: Armonk, NY, USA, 2017.

29. Chen, Z.; Schols, H.A.; Voragen, A.G.J. Physicochemical properties of starches obtained from three varieties of Chinese sweet potatoes. J. Food Sci. 2003, 68, 431-437. [CrossRef]

30. Nedunchezhiyan, M.; Byju, G.; Jata, S.K. Sweet potato agronomy. Fruit Veg. Cereal Sci. Biotechnol. 2012, 6, 1-10.

31. Farzana, Y.; Radizah, O. Influence of rhizobacterial inoculation on growth of the sweet potato cultivar. A.J. Bioc. Biot. 2005, 1, 176-179.

32. Szarvas, A.; Váraljai, T.; Monostori, T. Sweet potato production on alluvial soil with high clay content. Ann. Acad. Rom. Sci. Ser. Agric. Silvic. Vet. Med. Sci. 2017, 6, 68-75.

33. Masabni, J.; King, S. Easy Gardening; Texas A\&M Agrilife Extension: Collage Station, TX, USA, 2014; pp. 1-3.

34. Gai, J.P.; Feng, G.; Christie, P.; Li, X.L. Screening of Arbuscular Mycorrhizal Fungi for Symbiotic Efficiency with Sweet Potato. J. Plant Nutr. 2006, 29, 1085-1094. [CrossRef]

35. Alizadeh, O. Mycorrhizal symbiosis. Adv. Stud. Biol. 2011, 3, 273-281.

36. Ortas, I. The effect of mycorrhizal fungal inoculation on plant yield, nutrient uptake and inoculation effectiveness under long-term field conditions. Field Crop. Res. 2012, 125, 35-48. [CrossRef]

37. Rouphael, Y.; Franken, P.; Schneider, C.; Schwarz, D.; Giovannetti, M.; Agnolucci, M.; De Pascale, S.; Bonini, P.; Colla, G. Arbuscular mycorrhizal fungi act as biostimulants in horticultural crops. Sci. Hortic. 2015, 196, 91-108. [CrossRef]

38. Marschner, P. Rhizosphere biology. In Marschner's Mineral Nutrition of Higher Plants; Academic Press: Cambridge, MA, USA, 2012; pp. 369-388.

39. Pons, S.; Fournier, S.; Chervin, C.; Bécard, G.; Rochange, S.; Frei Dit Frey, N.; Puech Pagès, V. Phytohormone production by the arbuscular mycorrhizal fungus Rhizophagus irregularis. PLoS ONE 2020, 15, e0240886. [CrossRef]

40. Piliarová, M.; Ondreičková, K.; Hudcovicová, M.; Mihálik, D.; Kraic, J. Arbuscular mycorrhizal fungi-their life and function in ecosystem. Agriculture 2019, 65, 3-15. [CrossRef]

41. Jin, H.; Liu, J.; Liu, J.; Huang, X. Forms of nitrogen uptake, translocation, and transfer via arbuscular mycorrhizal fungi: A review. Sci. China Life Sci. 2012, 55, 474-482. [CrossRef]

42. Krishnakumar, S.; Balakrishnan, N.; Muthukrishnan, R.; Kumar, S.R. Myth and mystery of soil mycorrhiza: A review. Afr. J. Agric. Res. 2013, 8, 4706-4717.

43. Ruiz-Sánchez, M.; Aroca, R.; Muñoz, Y.; Polón, R.; Ruiz-Lozano, J.M. The arbuscular mycorrhizal symbiosis enhances the photosynthetic efficiency and the antioxidative response of rice plants subjected to drought stress. J. Plant Physiol. 2010, 167, 862-869. [CrossRef] [PubMed]

44. Chen, S.; Zhao, H.; Zou, C.; Li, Y.; Chen, Y.; Wang, Z.; Jiang, Y.; Liu, A.; Zhao, P.; Wang, M.; et al. Combined Inoculation with Multiple Arbuscular Mycorrhizal Fungi Improves Growth, Nutrient Uptake and Photosynthesis in Cucumber Seedlings. Front. Microbiol. 2017, 8, 2516. [CrossRef] [PubMed]

45. Ortas, I.; Akpinar, Ç. Response of maize genotypes to several mycorrhizal inoculums in terms of plant growth, nutrient uptake and spore production. J. Plant Nutr. 2011, 34, 970-987. [CrossRef]

46. Kakabouki, I.; Mavroeidis, A.; Tataridas, A.; Kousta, A.; Efthimiadou, A.; Karydogianni, S.; Katsenios, N.; Roussis, I.; Papastylianou, P. Effect of Rhizophagus irregularis on Growth and Quality of Cannabis sativa Seedlings. Plants 2021, 10, 1333. [CrossRef] [PubMed]

47. Neumann, E.; Schmid, B.; Römheld, V.; George, E. Extraradical development and contribution to plant performance of an arbuscular mycorrhizal symbiosis exposed to complete or partial root zone drying. Mycorrhiza 2009, 20, 13-23. [CrossRef] 
48. Sakha, M.; Jefwa, J. Effects of Arbuscular Mycorrhizal Fungal Inoculation on Growth and Yield of Two Sweet Potato Varieties. J. Agric. Ecol. Res. Int. 2019, 18, 1-8. [CrossRef]

49. Reddy, R.; Soibam, H.; Ayam, V.S.; Panja, P.; Mitra, S. Morphological characterization of sweet potato cultivars during growth, development and harvesting. Indian J. Agric. Res. 2018, 52, 46-50. [CrossRef]

50. Martin, C.C. Rotary drum compost and compost tea as substrates, amendments, and biocontrol agents for damping-off (Pythium ultimum) management in tomato (Solanum lycopersicum). Ph.D. Thesis, University of the West Indies, St. Augustine, Trinidad and Tobago, September 2013.

51. Köhl, L.; Lukasiewicz, C.E.; Van Der Heijden, M.G.A. Establishment and effectiveness of inoculated arbuscular mycorrhizal fungi in agricultural soils. Plant Cell Environ. 2016, 39, 136-146. [CrossRef]

52. Perner, H.; Schwarz, D.; George, E. Effect of mycorrhizal inoculation and compost supply on growth and nutrient uptake of young leek plants growth on peat-based substrates. Hortic. Sci. 2006, 41, 628-632. [CrossRef]

53. Baum, C.; El-Tohamy, W.; Gruda, N. Increasing the productivity and product quality of vegetable crops using arbuscular mycorrhizal fungi: A review. Sci. Hortic. 2015, 187, 131-141. [CrossRef]

54. Wipf, D.; Krajinski, F.; van Tuinen, D.; Recorbet, G.; Courty, P.E. Trading on the arbuscular mycorrhiza market: From arbuscules to common mycorrhizal networks. New Phytol. 2019, 223, 1127-1142. [CrossRef] [PubMed] 